University of Louisville

ThinkIR: The University of Louisville's Institutional Repository

Electronic Theses and Dissertations

8-2005

\title{
Optimization of interhospital transfer of patients to reduce emergency department overcrowding.
}

Brandi Marie Hill 1980-

University of Louisville

Follow this and additional works at: https://ir.library.louisville.edu/etd

\section{Recommended Citation}

Hill, Brandi Marie 1980-, "Optimization of interhospital transfer of patients to reduce emergency department overcrowding." (2005). Electronic Theses and Dissertations. Paper 619.

https://doi.org/10.18297/etd/619

This Master's Thesis is brought to you for free and open access by ThinkIR: The University of Louisville's Institutional Repository. It has been accepted for inclusion in Electronic Theses and Dissertations by an authorized administrator of ThinkIR: The University of Louisville's Institutional Repository. This title appears here courtesy of the author, who has retained all other copyrights. For more information, please contact thinkir@louisville.edu. 


\title{
OPTIMIZATION OF INTERHOSPITAL TRANSFER OF PATIENTS TO REDUCE EMERGENCY DEPARTMENT OVERCROWDING
}

By

Brandi Marie Hill

B.S.I.E., University of Louisville, 2004

\author{
A Thesis \\ Submitted to the Faculty of the \\ University of Louisville \\ J.B. Speed School of Engineering \\ as Partial Fulfillment of the Requirements \\ for the Professional Degree \\ MASTER OF ENGINEERING \\ Department of Industrial Engineering \\ University of Louisville \\ Louisville, Kentucky
}

August 2005 


\section{OPTIMIZATION OF INTERHOSPITAL TRANSFER OF PATIENTS TO REDUCE EMERGENCY DEPARTMENT OVERCROWDING}

Submitted by:

Brandi Marie Hill

A Thesis Approved on

August 16, 2005

Date

By the Following Reading and Examination Committee:

Dr. Gail W. DePuy, Thesis Director

Dr. Gerald W. Evans

Dr. Eric Rouchka 


\section{ACKNOWLEDGEMENTS}

"And this is the confidence that we have in Him, that, if we ask anything according to His will, He heareth us: And if we know that He hear us, whatsoever we ask, we know that we have the petitions that we desire of Him." (1 John 5: 14-15)

I feel so blessed to have made it to this point, and I am appreciative of everyone who has helped me along the way. A heartfelt thank you goes out to my family and friends who have been a constant source of encouragement to me. I thank you, Mother, for being such an inspiration in my life. Thank you, Prof. Brenda Hart, for your guidance throughout my college career. Thank you, Dr. Gail DePuy, for your support and patience as my Thesis Director. I sincerely appreciate the time you spent working with me in regards to my thesis, and also as a student in general. I would also like to thank Dr. Gerald Evans, and Dr. Eric Rouchka for their time as members of my thesis committee. Finally, I would like to thank my professors, and everyone I have had an opportunity to work with as a student of the University of Louisville; my experiences were very positive and truly unforgettable. 


\begin{abstract}
The purpose of this research project is to evaluate the feasibility of interhospital patient transfers (within a hospital corporation referred to as NESW Hospital Co.) as a means of reducing emergency department overcrowding. Customer satisfaction is a highly weighted factor in the event of interhospital transferring of patients, as providing quality health care is of the utmost importance to the NESW Hospital Co. Interhospital patient transfers are considered in times of high patient volumes when the referring hospital lacks an available bed to care for those patients whom, via the emergency department, must be admitted to a nursing unit.
\end{abstract}

NESW Hospital Co. consists of four hospitals within a metropolitan area. In order to maintain consistency, four nursing units were chosen from each hospital. The nursing units selected for observation provide the same type of care across the facilities, and each has generally high utilization according to data provided by the corporation. Additionally, costs associated with transferring patients between facilities were provided by the corporation. A linear programming model along with sensitivity analysis was used in evaluating the transfer of patients from the emergency department of one hospital to the appropriate nursing unit of another.

The evaluation yields positive results. The Model 2 objective function value was $\$ 12,350$. This method of assigning transfer patients is economically feasible. The amount of time a patient must spend in the waiting area of the emergency department, or in an emergency room waiting to be assigned a bed within a nursing unit was 
significantly reduced. Additionally, transferring patients creates more space within the emergency departments and allows more patients to be treated. 


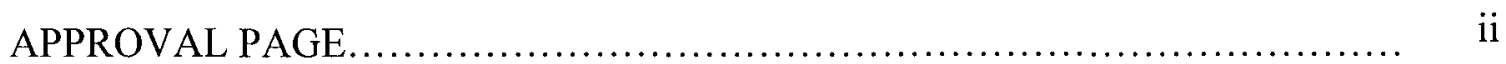

ACKNOWLEDGEMENTS .....................................................

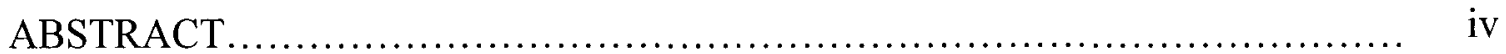

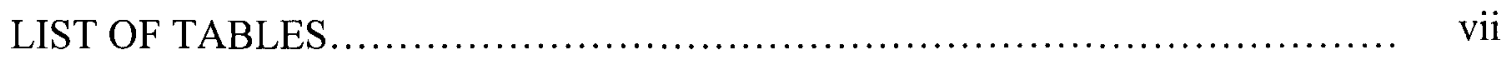

LIST OF FIGURES......................................................... vii

I. INTRODUCTION .....................................................

A. Background Information........................................ 1

B. Problem Definition............................................... 1

C. Research Goal.................................................. 2

II. LITERATURE REVIEW ................................................ 3

A. Emergency Department Overcrowding ............................ 3

B. Results of Interhospital Patient Transfers............................ 5

C. Response of Patients ............................................... 6

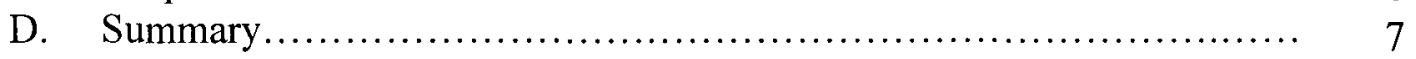

III. METHODOLOGY........................................................ 8

A. Collection of Data................................................. 8

B. Overview of Current Method of Handling Patients..................... 10

C. Linear Programming Model....................................... 12

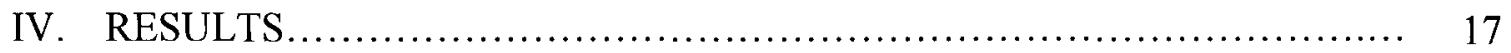

V. CONCLUSION AND RECOMMENDATIONS ........................... 22

VI. FUTURE RESEARCH............................................ 23

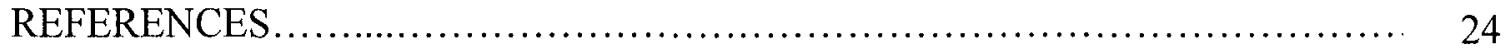

APPENDIX I. Linear Programming Model 1 MPL Formulation................... 25

APPENDIX II. Linear Programming Model 2 MPL Formulation................... 27

APPENDIX III. LINDO Sensitivity Analysis of Model 1 ........................ 29

APPENDIX IV. LINDO Sensitivity Analysis of Model 2 ...................... 36

CURRICULUM VITAE ...................................................... 43 


\section{LIST OF TABLES}

$\underline{\text { Page }}$

TABLE I: Costs to Transfer Patients between Hospitals......................... 9

TABLE II: Nursing Unit Capacity and Volume Information per Hospital........... 9

TABLE III: Emergency Department New Arrivals per Day of Each Type........... 10

TABLE IV: Summary of Transfer Results for Model $1 \ldots \ldots \ldots \ldots \ldots \ldots \ldots \ldots \ldots \ldots . \quad 18$

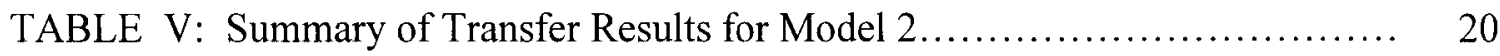




\section{LIST OF FIGURES}

$\underline{\text { Page }}$

FIGURE 1 - Flow Chart of the Emergency Department Current Process............ 11

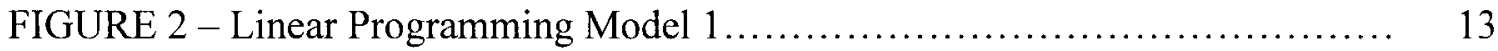

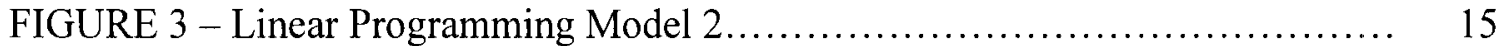

FIGURE 4 - Summary of Sensitivity Analysis Results for Model $1 \ldots \ldots \ldots \ldots \ldots \ldots . . \ldots$

FIGURE 5 - Summary of Sensitivity Analysis Results for Model 2 ............... 21 


\section{INTRODUCTION}

\section{A. Background Information}

NESW Hospital Co.' has been in existence for decades and consists of four hospitals within a metropolitan area. The hospitals are labeled North Hospital, East Hospital, South Hospital, and West Hospital in accordance with their location. ${ }^{2}$ NESW Hospital Co. desires to provide quality health care to patients, and customer satisfaction is very important in doing so. Each hospital acts under a uniform code of medical ethics and service methods in providing care to patients. Additionally, an adult patient base is common to each hospital.

Currently, the procedure for handling patients that arrive by ambulance to the emergency department is to place the patient in an emergency room and provide care immediately. Walk-in patients must first register, be assessed by a triage nurse, and then remain in the waiting area until they can be admitted into an emergency room. Subsequent to a physician evaluation within the emergency room, patients are either flagged for admission into a nursing unit within the hospital or properly discharged from the emergency department. In the event there are no beds available in the required nursing unit, patients occupy space in the emergency room until there is an opening.

1. In order to protect the privacy of the corporation, the title "NESW Hospital Co." is used in substitution of the official company name.

2. The hospital names have been changed to "North Hospital," "East Hospital," "South Hospital," and "West Hospital" for use in this research in order to protect their privacy. 


\section{B. Problem Definition}

Due to an extremely high volume of visiting patients and relatively low capacities, NESW Hospital Co. has experienced overcrowding within the emergency departments. Overcrowding in the emergency departments is due, in part, to inability to transfer patients to an appropriate nursing unit within the hospital because the unit is filled to capacity. NESW Hospital Co. wants to investigate the feasibility of interhospital transfer of patients as a means of reducing emergency department overcrowding related to lack of available space in the nursing units. The corporation places a high priority on customer service and satisfaction, and expects this evaluation will uphold its standards.

\section{Research Goal}

The purpose of this research is to mathematically model interhospital transfers from the emergency department of one hospital to a nursing unit of another. Several transfer policies are considered within the math model. Sensitivity analysis is performed to make recommendations on interhospital transfers to NESW Hospital Co. In addition to the emergency departments, four nursing units with high utilization were selected for review at each of the hospitals within the corporation. The units chosen were the Intensive Care Unit (ICU), Medical/Surgical Unit (M/S), Transitional Care Unit (TCU), and the Oncology Department (Oncol). 


\section{LITERATURE REVIEW}

Many emergency departments experience times of high utilization. In the United States alone, over 100 million patients visit an emergency department per fiscal year (Derlet, 2002). It is the overcrowding of most emergency departments that creates a problem for hospitals in the realm of emergency service. Often, hospitals employ creative methods to mitigate the effects of emergency department overcrowding. This literature review hones in on the causes, the effects, and the proposed methods of resolution of emergency department overcrowding. Additionally, specific attention will be given to interhospital transfer of patients as a method of resolution for emergency department overcrowding, and the general responses of patients will be duly noted.

\section{A. Emergency Department Overcrowding}

Inpatient services and nursing units at full capacity inhibit the ability of emergency departments to assign patients to the appropriate unit. As a result, the emergency department is the defaulted holding area for patients waiting for a bed to become available in a nursing unit (Derlet, 2002). The inability of a hospital nursing unit to serve multiple roles and provide service to a range of patient types is cited as a hindrance, since patients can not be transferred from the emergency department to any nursing unit with an available bed (Shih et al., 1999). Another contributing factor to the issue of overcrowding is that patients with illnesses/injuries that can be handled with home care methods (or in nursing homes) unnecessarily utilize space within emergency departments 
(Walsh et al., 2003). Occasionally, visitors to the emergency department are not even in need of emergency care and could have simply scheduled an appointment with their own doctor.

Often, bed space within the emergency department is highly utilized, but overcrowding negatively effects productivity and limits the ability to treat in-coming patients. The amount of time a patient must spend in the waiting room or in the department as a whole is increased by overcrowding. Patients that are in pain suffer longer, and a diagnosis of symptoms is delayed. Periodically, patients will leave without being seen by a physician after spending several hours in the waiting room (Derlet, 2002). Additionally, quality of care within the department is directly affected by overcrowding, as the demand on departmental staff is heightened by the needs of arriving patients, critical patients, and those patients that could not be instantly transferred to a nursing unit (Shih et al., 1999). Unfortunately, the worst of many possible effects of overcrowding is the increased risk of fatalities (Derlet, 2002).

Methods of resolving emergency department overcrowding may vary from one facility to the next. Hospitals with tremendous overcrowding have been known to issue a critical care bypass, closing the emergency department to ambulances needing to deliver patients (Derlet, 2002). Typically, ambulance drivers deliver patients to the nearest emergency department, so critical care bypass forces them to go further out of the way. In addition to critical care bypass, several hospitals place those patients waiting to be admitted to a nursing unit into the hallway outside of the emergency department or near the nursing unit, as a means of creating space for others to be treated (McNamee \& Kolb, 
2004). Other emergency departments are turning toward interhospital transferring of patients, when in-hospital management strategies fall short (Shih et al., 1999).

In order to improve the efficiency of emergency departments, some hospitals are turning toward case managers (Walsh et al., 2003). Case management is often used to determine whether or not admission is necessary for patients entering the emergency department. This type of screening is similar to triage nursing, as a level of priority is assigned to patients. Also, case managers make arrangements for patients to be properly discharged when the services provided by an emergency department no longer suit the needs of the patient, or the patient can be treated from home (Walsh et al., 2003).

\section{B. Results of Interhospital Patient Transfers}

Queues form in emergency departments, as the rate of arriving patients is considerably greater than the rate of departing patients. Interhospital transfer of patients is one method of handling overcrowding. According to Shih et al (1999), interhospital transfers are recommended for patients with relatively minor illnesses/injuries who have an extended wait due to lack of available space in an inpatient unit. An agreement about proper procedures must be established between all participating hospitals in the event of interhospital patient transfers (Shih et al., 1999). Bed capacities, current occupancies, administrative contact information, and approval status must be clear before a transfer takes place (Shih et al., 1999).

As with most methods of resolution, drawbacks are associated with interhospital patient transfers. The disadvantages of transferring patients from one hospital to another must be compared to potential improvements in the quality of care for patients (Hosseini- 
Nezhad et al., 1995). Shih et al (1999) explains that the income of the referring hospital decreases when emergency department patients are transferred out, and the possibility of rejection by a receiving hospital exists. Additionally, patients may be separated from their family in the event of transferring, which can add stress to an already stressful situation (Hosseini - Nezhad et al., 1995).

A number of considerations must be taken into account after the decision has been made to transfer patients from one hospital to the next. Transportation resources need to be properly allocated between participating hospitals (Hosseini - Nezhad et al., 1995). The mode of transportation (private ambulance, mobile intensive care unit, helicopter, etc.) must be decided as well (Hosseini - Nezhad et al., 1995). Additionally, staff must resolve multiple requests for transfers as only one patient can be transported at a time (Hosseini - Nezhad et al., 1995).

\section{Response of Patients}

Commonly, responses of patients vary when faced with the options for mitigating overcrowding. For example, McNamee and Kolb (2004) reported results from a survey regarding the preference of patients to board in the hallway outside of an emergency department or outside of an inpatient ward. Approximately two-thirds of the patients surveyed preferred to wait outside of the inpatient ward, and the other third preferred to wait outside of the emergency department (McNamee \& Kolb, 2004). Reasons listed ranged from less traffic, noise, and commotion found outside of the inpatient ward to a more comfortable, safe, and quiet environment outside of the emergency department (McNamee \& Kolb, 2004). 
According to Shih et al (1999), the responses received from an implemented survey suggest that patients are highly dissatisfied with long waiting times in the emergency department. Dissatisfaction with having to wait extended periods of time is evident when registered patients leave the waiting room without being seen by an emergency department physician (Derlet, 2002). In general, patients are wary about being transferred to a hospital they know little or nothing about (Shih et al., 1999). However, such transfers may significantly reduce the amount of time a patient must wait.

\section{Summary}

Although emergency department overcrowding is an issue with negative effects, many hospitals have found creative ways to help nullify those effects. Hospitals must find and employ methods to resolve overcrowding that work for both their staff and their patient base. Surveys can be used to gather information regarding the willingness of patients to participate in the chosen method of resolution. Regardless of the method chosen, research needs to be carried out regarding proper procedures, and the safety and well-being of handling patients must be the top priority. Generally, as long as patients feel secure and well cared for, and time is saved in the process, they respect the method of resolution. 


\section{METHODOLOGY}

\section{A. Collection of Data}

NESW Hospital Co. was instrumental in supplying data requested to investigate interhospital transfer of patients to reduce emergency department overcrowding when nursing units lack available space. Initially, results of a survey that had been distributed to stable patients in the emergency department of North Hospital, East Hospital, South Hospital, and West Hospital were shared and reviewed. The survey was intended to relay the response of patients in stable condition when faced with the option of being transferred from one hospital to another (Hurst, 2003). Survey results suggested that patients had little problem being transferred to another hospital within the corporation, as long as their waiting times were considerably reduced without any additional fees. In addition to the survey tool, NESW Hospital Co. provided data regarding the cost to transfer patients between hospitals, the departmental capacity information, and the data related to average volume and emergency department new arrivals.

Data regarding the cost to transfer patients by ambulance from the emergency department of one hospital to a nursing unit of another hospital was provided. The transfer costs to and from any two hospitals is equivalent. Additionally, the costs of transferring patients from the emergency department to a nursing unit within the same hospital were provided. Intrahospital transfer of patients is less expensive and preferred when possible, but is only an option when space is available within the nursing units. Transfer cost information is shown in TABLE I below. 
TABLE I. Costs to Transfer Patients between Hospitals

\begin{tabular}{|l|c|}
\hline \multicolumn{1}{|c|}{ Hospital } & Transfer Cost \\
\hline North $\leftrightarrow$ North & $\$ 75$ \\
\hline North $\leftrightarrow$ East & $\$ 255$ \\
\hline North $\leftrightarrow$ South & $\$ 275$ \\
\hline North $\leftrightarrow$ West & $\$ 285$ \\
\hline East $\leftrightarrow$ East & $\$ 75$ \\
\hline East $\leftrightarrow$ South & $\$ 265$ \\
\hline East $\leftrightarrow$ West & $\$ 275$ \\
\hline South $\leftrightarrow$ South & $\$ 75$ \\
\hline South $\leftrightarrow$ West & $\$ 285$ \\
\hline West $\leftrightarrow$ West & $\$ 75$ \\
\hline
\end{tabular}

The ICU, M/S, TCU, and Oncol nursing units at each hospital within NESW Hospital Co. have individual capacity limits. Also, the number of patients who occupy bed space within each of the above mentioned units changes daily. However, the expected number of patients who occupy nursing unit bed space per day were provided and used for the purposes of this study. In TABLE II below, capacity information and volume data of each hospital nursing unit are shown.

TABLE II. Nursing Unit Capacity and Volume Information per Hospital

\begin{tabular}{|c|c|c|c|}
\hline Hospital & Unit & Capacity & $\begin{array}{c}\text { Average } \\
\text { Volume }\end{array}$ \\
\hline \multirow{4}{*}{ North } & ICU & 50 & 25 \\
\cline { 2 - 4 } & M/S & 89 & 63 \\
\cline { 2 - 4 } & TCU & 75 & 39 \\
\cline { 2 - 4 } & Oncol & 38 & 19 \\
\hline \multirow{4}{*}{ East } & ICU & 24 & 24 \\
\cline { 2 - 4 } & M/S & 59 & 58 \\
\cline { 2 - 4 } & TCU & 55 & 53 \\
\cline { 2 - 4 } & Oncol & 32 & 15 \\
\hline \multirow{5}{*}{ South } & ICU & 24 & 9 \\
\cline { 2 - 4 } & M/S & 60 & 60 \\
\cline { 2 - 4 } & \hline TCU & 40 & 21 \\
\cline { 2 - 4 } & Oncol & 32 & 14 \\
\hline \multirow{4}{*}{ West } & ICU & 20 & 20 \\
\cline { 2 - 4 } & M/S & 40 & 39 \\
\cline { 2 - 4 } & TCU & 35 & 34 \\
\cline { 2 - 4 } & Oncol & 25 & 10 \\
\hline
\end{tabular}


In addition to the average volume data, there are an expected number of new arrivals to the emergency departments of each hospital who must, in turn, be admitted to a nursing unit. The number of new arrivals to each emergency department who must be admitted to a nursing unit varies in type, meaning the patients are ICU, M/S, TCU, or Oncol patients. TABLE III below indicates the expected number of new arrivals of each type to the individual hospital emergency departments per day.

TABLE III. Emergency Department New Arrivals per Day of Each Type

\begin{tabular}{|c|c|c|}
\hline $\begin{array}{l}\text { Emergency } \\
\text { Department }\end{array}$ & Type & $\begin{array}{c}\text { New } \\
\text { Arrivals }\end{array}$ \\
\hline \multirow{4}{*}{ North } & ICU & 2 \\
\hline & $\mathrm{M} / \mathrm{S}$ & $\overline{6}$ \\
\hline & TCU & 3 \\
\hline & Oncol & $\bar{~} 5$ \\
\hline \multirow{4}{*}{ East } & $\mathrm{ICU}$ & 3 \\
\hline & $\mathrm{M} / \mathrm{S}$ & 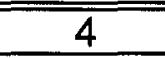 \\
\hline & $\overline{T C U}$ & 3 \\
\hline & Oncol & $\overline{\overline{4} 4}$ \\
\hline \multirow{4}{*}{ South } & $\mathrm{ICU}$ & 2 \\
\hline & $\mathrm{M} / \mathrm{S}$ & 10 \\
\hline & TCU & $\overline{5}$ \\
\hline & OOncol & $\overline{14}$ \\
\hline \multirow{4}{*}{ West } & $\mathrm{ICU}$ & 1 \\
\hline & $\overline{\mathrm{M} / \mathrm{S}}$ & $\overline{8}$ \\
\hline & $\overline{\mathrm{TCCU}}$ & 7 \\
\hline & OOncol & 5 \\
\hline
\end{tabular}

Once all of the necessary data was collected, it was then reviewed. The data was used to provide insight into the NESW Hospital Co. issue of emergency department overcrowding due to lack of available space in the nursing units. The next step was to detail and analyze the current method in which NESW Hospital Co. handles patients. 


\section{B. Overview of Current Method of Handling Patients}

Currently, there are two ways in which NESW Hospital Co. handles emergency department arrivals. Patients who arrive at an emergency department by ambulance are immediately given an emergency room and provided with care. Walk-in patients must first register, sit through a triage nurse priority assessment, and then wait to be admitted into an emergency room. Subsequent to a physician evaluation within the emergency room, patients are either flagged for admission into a nursing unit within the hospital or properly discharged from the emergency department. In the event there are no beds available in the required nursing unit, patients occupy space in the emergency room until there is an opening. FIGURE 1 below shows a flow chart of the current process of handling patients in the emergency department.

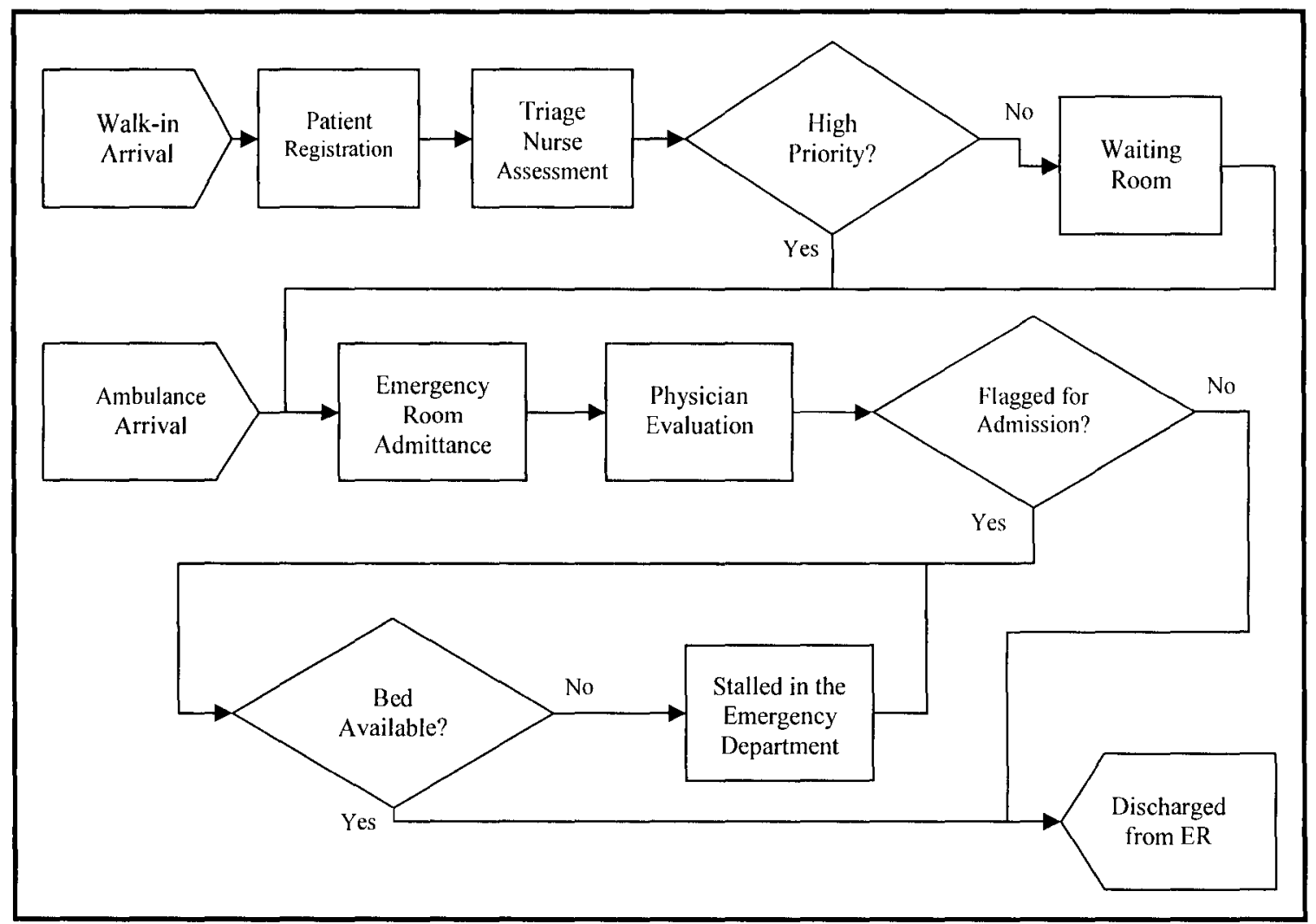

FIGURE 1 - Flow Chart of the Emergency Department Current Process 
In creating space for new patient arrivals, it is critical that the emergency departments continually discharge patients. In doing so, a drastic reduction must occur in the number of patients who are stalled in emergency departments waiting for a nursing unit bed to become available. The waiting time for patients needing to be transferred from an emergency department to a specific nursing unit that is already at full capacity is indefinite. Presently, there is no system in place to help remedy such a delay.

NESW Hospital Co. wants their North, East, South, and West Hospitals to collaborate on interhospital transfer of patients as an initiative to help reduce excessive waiting times in the emergency departments. Excessive waiting times are considered by NESW Hospital Co. to be three hours or more without the prospect of being transferred to a nursing unit. Such an initiative is an attempt to reduce emergency department overcrowding. The intent of the combined efforts of the hospitals is to create space for new patient arrivals, and in turn increase the productivity of the emergency departments. As an end result, NESW Hospital Co. wants their customers to be completely satisfied with the quality of services provided.

\section{Linear Programming Model}

In evaluating the transfer of patients from the emergency department of one hospital to the appropriate nursing unit of another, a set of two linear programming models were created. The main objective of the models is to minimize the cost of transferring patients from the emergency department to a nursing unit. These models include considerations for the number of patients being transferred out of the emergency department, the current number of patients in each nursing unit, and the capacity of the nursing units within each 
hospital. The approach taken in each model varies in an attempt to give NESW Hospital Co. a couple of options from which to choose regarding the interhospital transfer policy.

The overall goal is to choose the option that best suits the needs of each facility within NESW Hospital Co. Initially, a model was created to balance the number of each type of patient (i.e., ICU, TCU, M/S, ONCOL) at all four hospitals. In Model 1, the intent was to evenly distribute patients among the nursing units at each of the four hospitals while remaining within the capacity limits. The decision variables, objective function, and constraints for Model 1 are shown in FIGURE 2 below.

Decision Variables

$X_{i j k}=$ Number of ER patients at hospital $i$ of type $j$ transferred to a nursing unit within hospital $k$ where $i, j, k=\{1, . .4\}$

Objective Function

MIN $\sum_{i} \sum_{j} \sum_{k} C_{i j k} X_{i j k}$

$C_{i j k}=$ Per patient cost of transfers from ER of hospital $i$ of type $j$ to hospital $k$

Subject to

Constraints

$B_{j k}=$ Capacity of unit $j$ at hospital $k$

$A_{j k}=$ Current number of patients of type $j$ in hospital $k$

$N_{i j}=$ Number of new patients of type $j$ who arrive at the ER of hospital $i$

$\begin{array}{ll}\sum_{i} X_{i j k} \leq B_{j k}-A_{j k} & \forall j, k \\ \sum_{k} X_{i j k}=N_{i j} & \forall i, j\end{array}$

$A_{j k}+\sum_{i} X_{i j k} \geq 0.15\left(\sum_{k} A_{j k}+\sum_{i} \sum_{k} X_{i j k}\right) \quad \forall j, k$

FIGURE 2 - Linear Programming Model 1 
The objective function (1), shown in FIGURE 2, involves the minimization of the total cost for all patients of type $\mathrm{j}$ transferred from the emergency department in hospital $\mathrm{i}$ to the appropriate nursing unit in hospital k. North, East, South, and West Hospitals are represented by $\mathrm{i}$ and $\mathrm{k}$. ICU, $\mathrm{M} / \mathrm{S}$, TCU, and $\mathrm{ONCOL}$ are represented by $\mathrm{j}$. Constraint (2) ensures that the capacity of each nursing unit is not exceeded in the event of transfers from the emergency department. Constraint (3) makes sure the new patients of type j who arrive at the emergency department of hospital $\mathrm{i}$ are indeed transferred to the appropriate nursing unit of hospital k. Finally, constraint (4) of Model 1 balances type j patients among each of the hospitals making sure every nursing unit has a least 15 percent of the specified type. The intended purpose of the 15 percent limiter is to ensure that each hospital is receiving patients without forcing the outcome by using a larger percentage.

A second model was created to limit the number of interhospital transfer patients accepted, so that the nursing unit beds are not counterproductively crowded with transfer patients. Model 2 makes sure intrahospital transfers are given top priority over transfers from a different facility. FIGURE 3 shows the decision variables, objective function, and constraints for Model 2. 
Decision Variables

$X_{i j k}=$ Number of ER patients at hospital $i$ of type $j$ transferred to a nursing unit within hospital $k$

where $i, j, k=\{1, . ., 4\}$

Objective Function

MIN $\sum_{i} \sum_{j} \sum_{k} C_{i j k} X_{i j k}$

$C_{i j k}=$ Per patient cost of transfers from ER of hospital $i$ of type $j$ to hospital $k$

Subject to

Constraints

$B_{j k}=$ Capacity of unit $j$ at hospital $k$

$A_{j k}=$ Current number of patients of type $j$ in hospital $k$

$N_{i j}=$ Number of new patients of type $j$ who arrive at the ER of hospital $i$

$\sum_{i} X_{i j k} \leq B_{j k}-A_{j k} \quad \forall j, k$

$\sum_{k} X_{i j k}=N_{i j} \quad \forall i, j$

$\sum_{i \neq k} X_{i j k} \leq 0.80\left(B_{j k}-A_{j k}\right) \quad \forall j, k$

FIGURE 3 - Linear Programming Model 2

Notice that the decision variable and objective function (1) for Models 1 and 2 respectively in FIGURE 1 and FIGURE 2, are the same. The models differ in the assortment of constraints applied in order to best meet the objective. Also, constraint (2) and constraint (3) of Model 2 are unchanged from Model 1 constraints. The difference between Model 1 and Model 2 is found in the constraint (4) of each model. In Model 2, constraint (4) states that the number of patients transferred to a different facility is less than or equal to 80 percent of the available space in the receiving hospital. The 80 percent limiter of the combined interhospital transfer patients arriving at the receiving hospital ensures that at least 20 percent of the available space is reserved for in-hospital 
patient transfers. The purpose of creating the limiter was to reserve space for in-hospital patient transfers without significantly forcing the outcome.

In order to make a proper decision about the best model choice for the purpose of determining the feasibility of interhospital transfer of patients to reduce emergency department overcrowding, both Models 1 and 2 had to be tested. The section that follows addresses the results of both Model 1 and Model 2. 


\section{RESULTS}

The concepts in each of the aforementioned linear programming models were formulated using the MPL software program. The models were then solved with LINDO software for the purpose of conducting the sensitivity analysis. Sensitivity analysis was used in helping make recommendations regarding interhospital transfer of patients to NESW Hospital Co. A detailed listing of the MPL formulations and the LINDO sensitivity analysis are listed as a part of the appendices. The linear programming MPL formulation of Model 1 can be found in APPENDIX I. The Model 2 MPL formulation is detailed in APPENDIX II. In APPENDIX III, the LINDO sensitivity analysis of Model 1 is detailed. Additionally, the LINDO sensitivity analysis of Model 2 is listed in APPENDIX IV.

Particular attention was paid to the reduced cost and dual prices within each sensitivity analysis. In reviewing the reduced cost for each of the minimization models developed, a determination can be made as to how much the objective coefficient can be decreased before the optimal solution changes. The dual prices are indicative of an increase in profit for an additional unit of resource, as long as it is within the allowable ranges.

A solution was found for each linear programming model. The results in each case were specific to the given capacity limits and average volume of the nursing units, and to the expected number of emergency department new arrivals given. The cost of interhospital transfer of patients from the emergency room to a nursing unit was 
minimized. In APPENDIX III and APPENDIX IV, the LINDO Sensitivity Analyses of Models 1 and 2, respectively, show that where a value is assigned to a variable the reduced cost is in turn 0.00 .

Model 1 yielded an optimal solution of $\$ 12,359$. TABLE IV below summarizes the transfer results of Model 1. In APPENDIX III, the reduced cost section yields values ranging from 170.0 to 420.0 where there are no values assigned to the corresponding variable. Each of the values in the reduced cost section represent how much the objective coefficient can be decreased before a change will be evident in the optimal solution.

TABLE IV. Summary of Transfer Results for Model 1

\begin{tabular}{|c|c|c|c|}
\hline \multicolumn{4}{|c|}{ Model 1 } \\
\hline $\begin{array}{c}\text { Transferring } \\
\text { Hospital } \\
(\boldsymbol{i})\end{array}$ & $\begin{array}{c}\text { Unit/Type } \\
(\boldsymbol{j})\end{array}$ & $\begin{array}{c}\text { Receiving } \\
\text { Hospital } \\
(\boldsymbol{k})\end{array}$ & $\boldsymbol{X}_{\boldsymbol{i j k} \boldsymbol{k}}$ \\
\hline 1 & 1 & 1 & 2.00 \\
2 & 1 & 1 & 2.10 \\
\hline \hline 1 & 2 & 1 & 6.00 \\
2 & 2 & 1 & 3.00 \\
3 & 2 & 1 & 10.00 \\
4 & 2 & 1 & 7.00 \\
\hline \hline 1 & 3 & 1 & 3.00 \\
2 & 3 & 1 & 1.00 \\
\hline \hline 1 & 4 & 1 & 5.00 \\
\hline 2 & 2 & 2 & 1.00 \\
\hline \hline 2 & 3 & 2 & 2.00 \\
\hline 2 & 4 & 2 & 4.00 \\
\hline 2 & 1 & 3 & 0.90 \\
3 & 1 & 3 & 2.00 \\
4 & 1 & 3 & 1.00 \\
\hline \hline 3 & 3 & 3 & 5.00 \\
4 & 3 & 3 & 6.00 \\
\hline \hline 3 & 4 & 3 & 14.00 \\
\hline \hline 4 & 2 & 4 & 1.00 \\
\hline \hline 4 & 3 & 4 & 1.00 \\
\hline 4 & 4 & 4 & 5.00 \\
\hline
\end{tabular}


Additionally, the sensitivity analysis of Model 1 indicates that where the slack or surplus is 0.00 the dual prices section reflects a nonzero value. There is an increase in the objective value for each unit of resource listed within the dual prices section as long as they are within the allowable ranges. In APPENDIX III, the objective coefficient ranges in which the basis is unchanged are listed. Allowable increase and decrease values of 0.00 were found in the output, therefore there are multiple optimal solutions for Model 1. Lastly, there is flexibility in the allowable ranges for the basis to remain feasible, shown in the righthand side ranges of APPENDIX III. A brief summary of the sensitivity analysis results for Model 1 are detailed in FIGURE 4 below.

\section{Model 1}

a. Dual prices when slack or surplus is zero.

\begin{tabular}{|c|c|c|c|c|}
\hline Constraint & $\begin{array}{c}\text { Unit/Type } \\
(\boldsymbol{j})\end{array}$ & $\begin{array}{c}\text { Receiving } \\
\text { Hospital } \\
(\boldsymbol{k})\end{array}$ & $\begin{array}{c}\text { Slack or } \\
\text { Surplus }\end{array}$ & $\begin{array}{c}\text { Dual } \\
\text { Prices }\end{array}$ \\
\hline$(2)$ & 1 & 2 & 0.0 & 180.0 \\
\hline$(2)$ & 1 & 4 & 0.0 & 200.0 \\
\hline$(2)$ & 2 & 2 & 0.0 & 180.0 \\
\hline$(2)$ & 2 & 3 & 0.0 & 200.0 \\
\hline$(2)$ & 2 & 4 & 0.0 & 210.0 \\
\hline$(2)$ & 3 & 2 & 0.0 & 180.0 \\
\hline$(2)$ & 3 & 4 & 0.0 & 210.0 \\
\hline
\end{tabular}

b. Allowable increase and decrease values of zero.

\begin{tabular}{|c|c|c|c|}
\hline Variable & $\begin{array}{c}\text { Current } \\
\text { Coefficient }\end{array}$ & $\begin{array}{c}\text { Allowable } \\
\text { Increase }\end{array}$ & $\begin{array}{c}\text { Allowable } \\
\text { Decrease }\end{array}$ \\
\hline$X_{431}$ & 285.0 & $\infty$ & 0.0 \\
\hline$X_{433}$ & 285.0 & 0.0 & 210.0 \\
\hline
\end{tabular}

FIGURE 4 - Summary of Sensitivity Analysis Results for Model 1

The optimal solution of Model 2 is $\$ 12,350$. Within the reduced cost section of APPENDIX IV, values range from 170.0 to 420.0 as well. TABLE V below summarizes the transfer results of Model 2. Additionally, dual prices are reflected in the sensitivity 
analysis of Model 2 in each instance where the slack or surplus is 0.00 . There are multiple solutions for Model 2, as several of the allowable ranges listed in APPENDIX IV equal 0.00 . The righthand side ranges of the Model 2 sensitivity analysis reflect the allowable ranges for the basis to remain feasible. A brief summary of the sensitivity analysis results for Model 2 are detailed in FIGURE 5 below.

TABLE V. Summary of Transfer Results for Model 2

\begin{tabular}{|c|c|c|c|}
\hline \multicolumn{4}{|c|}{ Model 2 } \\
\hline $\begin{array}{c}\text { Transferring } \\
\text { Hospital } \\
(\boldsymbol{i})\end{array}$ & $\begin{array}{c}\text { Receiving } \\
\text { Unit/Type } \\
(\boldsymbol{j})\end{array}$ & $\begin{array}{c}\text { Hospital } \\
(\boldsymbol{k})\end{array}$ & $\boldsymbol{X}_{\boldsymbol{i j k} \boldsymbol{k}}$ \\
\hline 1 & 1 & 1 & 2.00 \\
2 & 1 & 1 & 3.00 \\
4 & 1 & 1 & 1.00 \\
\hline \hline 1 & 2 & 1 & 6.00 \\
2 & 2 & 1 & 3.00 \\
3 & 2 & 1 & 10.00 \\
4 & 2 & 1 & 7.00 \\
\hline \hline 1 & 3 & 1 & 3.00 \\
2 & 3 & 1 & 1.00 \\
\hline \hline 1 & 4 & 1 & 5.00 \\
\hline 2 & 2 & 2 & 1.00 \\
\hline \hline 2 & 3 & 2 & 2.00 \\
\hline \hline 2 & 4 & 2 & 4.00 \\
\hline 3 & 1 & 3 & 2.00 \\
\hline \hline 3 & 3 & 3 & 5.00 \\
4 & 3 & 3 & 6.00 \\
\hline \hline 3 & 4 & 3 & 14.00 \\
\hline 4 & 2 & 4 & 1.00 \\
\hline \hline 4 & 3 & 4 & 1.00 \\
\hline \hline 4 & 4 & 4 & 5.00 \\
\hline
\end{tabular}




\section{Model 2}

a. Dual prices when slack or surplus is zero.

\begin{tabular}{|c|c|c|c|c|}
\hline Constraint & $\begin{array}{c}\text { Unit/Type } \\
(\boldsymbol{j})\end{array}$ & $\begin{array}{c}\text { Receiving } \\
\text { Hospital } \\
(\boldsymbol{k})\end{array}$ & $\begin{array}{c}\text { Slack or } \\
\text { Surplus }\end{array}$ & $\begin{array}{c}\text { Dual } \\
\text { Prices }\end{array}$ \\
\hline$(2)$ & 1 & 2 & 0.0 & 180.0 \\
\hline$(2)$ & 1 & 4 & 0.0 & 210.0 \\
\hline$(2)$ & 2 & 2 & 0.0 & 180.0 \\
\hline$(2)$ & 2 & 3 & 0.0 & 200.0 \\
\hline$(2)$ & 2 & 4 & 0.0 & 210.0 \\
\hline$(2)$ & 3 & 2 & 0.0 & 180.0 \\
\hline$(2)$ & 3 & 4 & 0.0 & 210.0 \\
\hline
\end{tabular}

b. Allowable increase and decrease values of zero.

\begin{tabular}{|c|c|c|c|}
\hline Variable & $\begin{array}{c}\text { Current } \\
\text { Coefficient }\end{array}$ & $\begin{array}{c}\text { Allowable } \\
\text { Increase }\end{array}$ & $\begin{array}{c}\text { Allowable } \\
\text { Decrease }\end{array}$ \\
\hline$X_{411}$ & 285.0 & 0.0 & 210.0 \\
\hline$X_{413}$ & 285.0 & $\infty$ & 0.0 \\
\hline$X_{431}$ & 285.0 & $\infty$ & 0.0 \\
\hline$X_{433}$ & 285.0 & 0.0 & 210.0 \\
\hline
\end{tabular}

FIGURE 5 - Summary of Sensitivity Analysis Results for Model 2 


\section{CONCLUSION AND RECOMMENDATIONS}

Since the difference in the objective function values of Model 1 and Model 2 is only $\$ 9$ in favor of Model 2, and there is flexibility in the allowable ranges, the deciding factor in selecting the best model was not cost alone. Model 2 was selected as the best model for NESW Hospital Co. to choose in their effort to reduce emergency department overcrowding due to lack of available space in the nursing units. The results of Model 2 were less costly using the given capacity limits and average volume of the nursing units, and the expected number of emergency department new arrivals given. Additionally, Model 2 ensures that nursing unit beds are not counterproductively filled with interhospital transfer patients.

The evaluation results prove positive. In summary, the amount of time a patient must spend in the waiting area of the emergency department, or in an emergency room waiting to be assigned a bed within a nursing unit is considerably reduced. Additionally, transferring patients creates more space within the emergency departments and allows more patients to be treated. Both methods of assigning transfer patients are economically feasible. However, Model 2 is the best choice in meeting the overall goal, and ensuring intrahospital transfer is always given top priority. 


\section{FUTURE RESEARCH}

The linear programming model detailed in the preceding sections can be employed immediately to help reduce emergency department overcrowding within NESW Hospital Co. In the future, NESW Hospital Co. should consider increasing capacity within hospital nursing units that continuously prohibit in-hospital patient transfers. The objective should be to ensure every patient is provided a bed, while minimizing the number of patients needing to be transferred to a different facility.

In meeting the objective, attention must be given to those nursing units that are consistently at full capacity. Since creating space in an existing facility can be a complicated, costly and time consuming process, NESW Hospital Co. should continue to use the linear programming model as a resource during the transition. Additionally, nursing units that are considerably under capacity should be evaluated, and possibly used for additional space. 


\section{REFERENCES}

Derlet, Robert W. "Overcrowding in Emergency Departments: Increased Demand and Decreased Capacity." Annals of Emergency Medicine 39.4 (2002): 430 - 432.

Graff, L.G., et al. "Effect of Interhospital Transfer Patterns on Hospitals' Quality Performance Measurement Results." Annals of Emergency Medicine 44.4 (2004): S116.

Hillier, Frederick S., and Gerald J. Lieberman. Introduction to Operations Research. $7^{\text {th }}$ ed. New York: McGraw - Hill, 2001.

Hosseini-Nezhad, Seyed M., et al. "A Neural Network Approach for the Determination of Interhospital Transport Mode." Computers and Biomedical Research 28 (1995): $319-334$.

Hurst, Kyle W. "Analysis of Hospital Patient Transfers." MEng Thesis. Department of Industrial Engineering. University of Louisville, 2003.

McNamee, C.S., and J. Kolb. "Emergency Department Overcrowding: Patient Preference for Boarding Hallway Location." Annals of Emergency Medicine 44.4 (2004): S115.

Schull, M.J., et al. "Emergency Department Overcrowding and Ambulance Transport Delays for Patients with Chest Pain." Annals of Emergency Medicine 43.3 (2004): $425-426$.

Shih, Fuh-Yuan, et al. "ED Overcrowding in Taiwan: Facts and Strategies." American Journal of Emergency Medicine 17.2 (1999): 198 - 202.

Walsh, Kathleen, Peter Moran, and Christine Greenwood. "A Successful Emergency Department Case Management Practice Model." The Case Manager 14.6 (2003): $54-57$. 


\section{APPENDICES}

\section{APPENDIX I - Linear Programming Model 1 MPL Formulation}

North Hospital $=1$, East $=2$, South $=3$, West $=4$

$\mathrm{ICU}=1, \mathrm{M} / \mathrm{S}=2, \mathrm{TCU}=3, \mathrm{ONCOL}=4$

TITLE

ThesisModel1;

INDEX

Hospi := 1..4;

Typej :=1..4;

Hospk :=1..4;

DATA

Cost[Hospi,Typej,Hospk] := (75, 255, 275, 285, 75, 255, 275, 285,

$75,255,275,285,75,255,275,285$, $255,75,265,275,255,75,265,275$, $255,75,265,275,255,75,265,275$, $275,265,75,285,275,265,75,285$, $275,265,75,285,275,265,75,285$, $285,275,285,75,285,275,285,75$, $285,275,285,75,285,275,285,75)$;

Current[Typej,Hospk] := $(25,24,9,20$,

$63,58,60,39$,

$39,53,21,34$, 
$19,15,14,10)$;

Capacity[Typej,Hospk] := (50, 24, 24, 20,

$89,59,60,40$,

$75,55,40,35$,

$38,32,32,25)$;

New[Hospi,Typej] := (2, 6, 3, 5,

$3,4,3,4$,

$2,10,5,14$,

$1,8,7,5)$;

Percent $:=0.15$

VARIABLES

Patients[Hospi,Typej,Hospk] -> Pats;

MODEL

MIN TotalCost $=$ SUM(Hospi,Typej,Hospk: Cost * Patients);

SUBJECT TO

HospCapacity[Typej,Hospk] -> HospCap:

SUM(Hospi: Patients) + Current - Capacity $<=0$;

HospTypes[Hospi,Typej] -> HospTyp:

SUM(Hospk: Patients) - New $=0$;

HospMinimum[Typej,Hospk] -> HospMin:

Current + SUM(Hospi: Patients) - SUM(Hospi,Hospk: Percent*Patients) -

SUM(Hospk: Percent*Current) $>=0$;

END 
North Hospital $=1$, East $=2$, South $=3$, West $=4$

$\mathrm{ICU}=1, \mathrm{M} / \mathrm{S}=2, \mathrm{TCU}=3, \mathrm{ONCOL}=4$

TITLE

ThesisModel2;

\section{INDEX}

Hospi :=1..4;

Typej $:=1 . .4$;

Hospk $:=1 . .4$

DATA

Cost[Hospi,Typej,Hospk] := (75, 255, 275, 285, 75, 255, 275, 285, $75,255,275,285,75,255,275,285$, $255,75,265,275,255,75,265,275$, $255,75,265,275,255,75,265,275$, $275,265,75,285,275,265,75,285$, $275,265,75,285,275,265,75,285$, $285,275,285,75,285,275,285,75$, $285,275,285,75,285,275,285,75)$;

Current[Typej,Hospk] := $(25,24,9,20$,

$$
\begin{aligned}
& 63,58,60,39, \\
& 39,53,21,34, \\
& 19,15,14,10) ;
\end{aligned}
$$

Capacity[Typej,Hospk] := (50, 24, 24, 20, 
$89,59,60,40$

$75,55,40,35$,

$38,32,32,25)$

New[Hospi,Typej] :=(2,6,3,5,

$3,4,3,4$,

$2,10,5,14$

$1,8,7,5)$

Rate $:=.60$

VARIABLES

Patients[Hospi,Typej,Hospk] -> Pats;

MODEL

MIN TotalCost $=$ SUM(Hospi,Typej,Hospk: Cost * Patients);

SUBJECT TO

HospCapacity[Typej,Hospk] -> HospCap:

SUM(Hospi: Patients) + Current - Capacity $<=0$;

HospTypes[Hospi,Typej] -> HospTyp:

SUM(Hospk: Patients) - New $=0$;

HospRates[Typej, Hospk] -> HospRat:

SUM(Hospi,Typej,Hospk $=$ Hospi: Patients $)-$ Rate $*$ Capacity + Current $>=0$;

END 
LP OPTIMUM FOUND AT STEP 19

OBJECTIVE FUNCTION VALUE

1) $\quad 12359.00$

\begin{tabular}{|c|c|c|}
\hline VARIABLE & VALUE & REDUCED COST \\
\hline PATS111 & 2.000000 & 0.000000 \\
\hline PATS 112 & 0.000000 & 360.000000 \\
\hline PATS1 13 & 0.000000 & 190.000000 \\
\hline PATS114 & 0.000000 & 410.000000 \\
\hline PATS121 & 6.000000 & 0.000000 \\
\hline PATS122 & 0.000000 & 360.000000 \\
\hline PATS123 & 0.000000 & 400.000000 \\
\hline PATS124 & 0.000000 & 420.000000 \\
\hline PATS131 & 3.000000 & 0.000000 \\
\hline PATS132 & 0.000000 & 360.000000 \\
\hline PATS133 & 0.000000 & 200.000000 \\
\hline PATS134 & 0.000000 & 420.000000 \\
\hline PATS141 & 5.000000 & 0.000000 \\
\hline PATS142 & 0.000000 & 180.000000 \\
\hline PATS143 & 0.000000 & 200.000000 \\
\hline PATS144 & 0.000000 & 210.000000 \\
\hline PATS211 & 2.100000 & 0.000000 \\
\hline PATS212 & 0.000000 & 0.000000 \\
\hline PATS213 & 0.900000 & 0.000000 \\
\hline PATS214 & 0.000000 & 220.000000 \\
\hline PATS221 & 3.000000 & 0.000000 \\
\hline PATS222 & 1.000000 & 0.000000 \\
\hline PATS223 & 0.000000 & 210.000000 \\
\hline PATS224 & 0.000000 & 230.000000 \\
\hline PATS231 & 1.000000 & 0.000000 \\
\hline PATS232 & 2.000000 & 0.000000 \\
\hline PATS233 & 0.000000 & 10.000000 \\
\hline PATS234 & 0.000000 & 230.000000 \\
\hline PATS241 & 0.000000 & 180.000000 \\
\hline PATS242 & 4.000000 & 0.000000 \\
\hline
\end{tabular}




$\begin{array}{lrr} & & \\ \text { PATS243 } & 0.000000 & 190.000000 \\ \text { PATS244 } & 0.000000 & 200.000000 \\ \text { PATS311 } & 0.000000 & 210.000000 \\ \text { PATS312 } & 0.000000 & 380.000000 \\ \text { PATS313 } & 2.000000 & 0.000000 \\ \text { PATS314 } & 0.000000 & 420.000000 \\ \text { PATS321 } & 10.000000 & 0.000000 \\ \text { PATS322 } & 0.000000 & 170.000000 \\ \text { PATS323 } & 0.000000 & 0.000000 \\ \text { PATS324 } & 0.000000 & 220.000000 \\ \text { PATS331 } & 0.000000 & 200.000000 \\ \text { PATS332 } & 0.000000 & 370.000000 \\ \text { PATS333 } & 5.000000 & 0.000000 \\ \text { PATS334 } & 0.000000 & 420.000000 \\ \text { PATS341 } & 0.000000 & 200.000000 \\ \text { PATS342 } & 0.000000 & 190.000000 \\ \text { PATS343 } & 14.000000 & 0.000000 \\ \text { PATS344 } & 0.000000 & 210.000000 \\ \text { PATS411 } & 0.000000 & 10.000000 \\ \text { PATS412 } & 0.000000 & 180.000000 \\ \text { PATS413 } & 1.000000 & 0.000000 \\ \text { PATS414 } & 0.000000 & 0.000000 \\ \text { PATS421 } & 7.000000 & 0.000000 \\ \text { PATS422 } & 0.000000 & 170.000000 \\ \text { PATS423 } & 0.000000 & 200.000000 \\ \text { PATS424 } & 1.000000 & 0.000000 \\ \text { PATS431 } & 0.000000 & 0.000000 \\ \text { PATS432 } & 0.000000 & 170.000000 \\ \text { PATS433 } & 6.000000 & 0.000000 \\ \text { PATS434 } & 1.000000 & 0.000000 \\ \text { PATS441 } & 0.000000 & 210.000000 \\ \text { PATS442 } & 0.000000 & 200.000000 \\ \text { PATS443 } & 0.000000 & 210.000000 \\ \text { PATS444 } & 5.000000 & 0.000000\end{array}$




\begin{tabular}{crr} 
ROW & SURPLUS & DUAL PRICES \\
\cline { 2 - 3 } HOSPCA11) & 20.900000 & 0.000000 \\
HOSPCA12) & 0.000000 & 180.000000 \\
HOSPCA13) & 11.100000 & 0.000000 \\
HOSPCA14) & 0.000000 & 200.000000 \\
HOSPCA21) & 0.000000 & 0.000000 \\
HOSPCA22) & 0.000000 & 180.000000 \\
HOSPCA23) & 0.000000 & 200.000000 \\
HOSPCA24) & 0.000000 & 210.000000 \\
HOSPCA31) & 32.000000 & 0.000000 \\
HOSPCA32) & 0.000000 & 180.000000 \\
HOSPCA33) & 8.000000 & 0.000000 \\
HOSPCA34) & 0.000000 & 210.000000 \\
HOSPCA41) & 14.000000 & 0.000000 \\
HOSPCA42) & 13.000000 & 0.000000 \\
HOSPCA43) & 4.000000 & 0.000000 \\
HOSPCA44) & 10.000000 & 0.000000 \\
HOSPMI11) & 16.200001 & 0.000000 \\
HOSPMI12) & 11.100000 & 0.000000 \\
HOSPMI13) & 0.000000 & -10.000000 \\
HOSPMI14) & 7.100000 & 0.000000 \\
HOSPMI21) & 51.799999 & 0.000000 \\
HOSPMI22) & 21.799999 & 0.000000 \\
HOSPMI23) & 22.799999 & 0.000000 \\
HOSPMI24) & 2.800000 & 0.000000 \\
HOSPMI31) & 18.250000 & 0.000000 \\
HOSPMI32) & 30.250000 & 0.000000 \\
HOSPMI33) & 7.250000 & 0.000000 \\
HOSPMI34) & 10.250000 & 0.000000 \\
HOSPMI41) & 11.100000 & 0.000000 \\
HOSPMI42) & 6.100000 & 0.000000 \\
HOSPMI43) & 15.100000 & 0.000000 \\
HOSPMI44) & 2.100000 & 0.000000 \\
HOSPTY11) & 0.000000 & -76.500000 \\
HOSPTY12) & 0.000000 & -75.000000 \\
HOSPTY13) & 0.000000 & -75.000000 \\
HOSP
\end{tabular}




$\begin{array}{llr}\text { HOSPTY14) } & 0.000000 & -75.000000 \\ \text { HOSPTY21) } & 0.000000 & -256.500000 \\ \text { HOSPTY22) } & 0.000000 & -255.000000 \\ \text { HOSPTY23) } & 0.000000 & -255.000000 \\ \text { HOSPTY24) } & 0.000000 & -75.000000 \\ \text { HOSPTY31) } & 0.000000 & -66.500000 \\ \text { HOSPTY32) } & 0.000000 & -275.000000 \\ \text { HOSPTY33) } & 0.000000 & -75.000000 \\ \text { HOSPTY34) } & 0.000000 & -75.000000 \\ \text { HOSPTY41) } & 0.000000 & -276.500000 \\ \text { HOSPTY42) } & 0.000000 & -285.000000 \\ \text { HOSPTY43) } & 0.000000 & -285.000000 \\ \text { HOSPTY44) } & 0.000000 & -75.000000\end{array}$

NO. ITERATIONS $=19$

RANGES IN WHICH THE BASIS IS UNCHANGED:

\begin{tabular}{|c|c|c|c|}
\hline \multirow[b]{2}{*}{ VARIABLE } & \multicolumn{3}{|c|}{ OBJ COEFFICIENT RANGES } \\
\hline & $\begin{array}{c}\text { CURRENT } \\
\text { COEF }\end{array}$ & $\begin{array}{l}\text { ALLOWABLE } \\
\text { INCREASE }\end{array}$ & $\begin{array}{l}\text { ALLOWABLE } \\
\text { DECREASE }\end{array}$ \\
\hline PATS1 11 & 75.000000 & 190.000000 & INFINITY \\
\hline PATS112 & 255.000000 & INFINITY & 360.000000 \\
\hline PATS113 & 275.000000 & INFINITY & 190.000000 \\
\hline PATS114 & 285.000000 & INFINITY & 410.000000 \\
\hline PATS121 & 75.000000 & 360.000000 & INFINITY \\
\hline PATS122 & 255.000000 & INFINITY & 360.000000 \\
\hline PATS123 & 275.000000 & INFINITY & 400.000000 \\
\hline PATS124 & 285.000000 & INFINITY & 420.000000 \\
\hline PATS131 & 75.000000 & 200.000000 & INFINITY \\
\hline PATS132 & 255.000000 & INFINITY & 360.000000 \\
\hline PATS133 & 275.000000 & INFINITY & 200.000000 \\
\hline PATS134 & 285.000000 & INFINITY & 420.000000 \\
\hline PATS141 & 75.000000 & 180.000000 & INFINITY \\
\hline PATS142 & 255.000000 & INFINITY & 180.000000 \\
\hline PATS143 & 275.000000 & INFINITY & 200.000000 \\
\hline PATS144 & 285.000000 & INFINITY & 210.000000 \\
\hline PATS211 & 255.000000 & 10.000000 & 180.000000 \\
\hline
\end{tabular}




\begin{tabular}{|c|c|c|c|}
\hline PATS212 & 75.000000 & 180.000000 & INFINITY \\
\hline PATS213 & 265.000000 & 190.000000 & 10.000000 \\
\hline PATS214 & 275.000000 & INFINITY & 220.000000 \\
\hline PATS221 & 255.000000 & 210.000000 & 0.000000 \\
\hline PATS222 & 75.000000 & 170.000000 & INFINITY \\
\hline PATS223 & 265.000000 & INFINITY & 210.000000 \\
\hline PATS224 & 275.000000 & INFINITY & 230.000000 \\
\hline ATS231 & 255.000000 & 10.000000 & 170.000000 \\
\hline PATS232 & 75.000000 & 170.000000 & INFINITY \\
\hline PATS233 & 265.000000 & INFINITY & 10.000000 \\
\hline PATS234 & 275.000000 & INFINITY & 230.000000 \\
\hline PATS241 & 255.000000 & INFINITY & 180.000000 \\
\hline PATS242 & 75.000000 & 180.000000 & INFINITY \\
\hline PATS243 & 265.000000 & INFINITY & 190.000000 \\
\hline PATS244 & 275.000000 & INFINITY & 200.000000 \\
\hline PATS311 & 275.000000 & INFINITY & 000 \\
\hline PATS312 & 265.000000 & INFINITY & 380.000000 \\
\hline PATS313 & 75.000000 & 210.000000 & INFINITY \\
\hline PATS314 & 285.000000 & INFINITY & 420.000000 \\
\hline PATS321 & 275 & 0000 & 000 \\
\hline PATS322 & 265.000000 & INFINITY & 170.000000 \\
\hline PATS323 & 75.000000 & 200.000000 & INFINITY \\
\hline PATS324 & 285.000000 & INFINITY & 220.000000 \\
\hline PATS331 & 275.000000 & INFINITY & 200.000000 \\
\hline PATS332 & 265.000000 & INFINITY & 370.000000 \\
\hline PATS333 & 75.000000 & 200.000000 & INFINITY \\
\hline PATS334 & 285.000000 & INFINITY & 420.000000 \\
\hline PATS341 & 275.000000 & INFINITY & 200.000000 \\
\hline PATS342 & 265.000000 & INFINITY & 190.000000 \\
\hline PATS343 & 75.000000 & 190.000000 & INFINITY \\
\hline PATS344 & 285.000000 & INFINITY & 210.000000 \\
\hline PATS411 & 285.000000 & INFINITY & 10.000000 \\
\hline PATS412 & 275.000000 & INFINITY & 180.000000 \\
\hline PATS413 & 285.000000 & 10.000000 & 200.000000 \\
\hline PATS414 & 75.000000 & 200.000000 & INFINITY \\
\hline PATS421 & 285.000000 & 170.000000 & 210.000000 \\
\hline PATS422 & 275.000000 & INFINITY & 170.00000 \\
\hline
\end{tabular}




$\begin{array}{lrrr}\text { PATS423 } & 285.000000 & \text { INFINITY } & 200.000000 \\ \text { PATS424 } & 75.000000 & 210.000000 & \text { INFINITY } \\ \text { PATS431 } & 285.000000 & \text { INFINITY } & 0.000000 \\ \text { PATS432 } & 275.000000 & \text { INFINITY } & 170.000000 \\ \text { PATS433 } & 285.000000 & 0.000000 & 210.000000 \\ \text { PATS434 } & 75.000000 & 210.000000 & \text { INFINITY } \\ \text { PATS441 } & 285.000000 & \text { INFINITY } & 210.000000 \\ \text { PATS442 } & 275.000000 & \text { INFINITY } & 200.000000 \\ \text { PATS443 } & 285.000000 & \text { INFINITY } & 210.000000 \\ \text { PATS444 } & 75.000000 & 200.000000 & \text { INFINITY }\end{array}$

RIGHTHAND SIDE RANGES

CURRENT ALLOWABLE ALLOWABLE

\begin{tabular}{crccc} 
ROW & \multicolumn{1}{c}{ RHS } & INCREASE & DECREASE \\
\cline { 5 - 5 } HOSPCA11 & 25.000000 & INFINITY & 20.900000 \\
HOSPCA12 & 0.000000 & 2.100000 & 0.000000 \\
HOSPCA13 & 15.000000 & INFINITY & 11.100000 \\
HOSPCA14 & 0.000000 & 1.000000 & 0.000000 \\
HOSPCA21 & 26.000000 & INFINITY & 0.000000 \\
HOSPCA22 & 1.000000 & 3.000000 & 0.000000 \\
HOSPCA23 & 0.000000 & 10.000000 & 0.000000 \\
HOSPCA24 & 1.000000 & 7.000000 & 0.000000 \\
HOSPCA31 & 36.000000 & INFINITY & 32.000000 \\
HOSPCA32 & 2.000000 & 1.000000 & 2.000000 \\
HOSPCA33 & 19.000000 & INFINITY & 8.000000 \\
HOSPCA34 & 1.000000 & 6.000000 & 1.000000 \\
HOSPCA41 & 19.000000 & INFINITY & 14.000000 \\
HOSPCA42 & 17.000000 & INFINITY & 13.000000 \\
HOSPCA43 & 18.000000 & INFINITY & 4.000000 \\
HOSPCA44 & 15.000000 & INFINITY & 10.000000 \\
HOSPMI11 & -13.300000 & 16.200001 & INFINITY \\
HOSPMI12 & -12.300000 & 11.100000 & INFINITY \\
HOSPMI13 & 2.700000 & 2.100000 & 0.900000 \\
HOSPMI14 & -8.300000 & 7.100000 & INFINITY \\
HOSPMI21 & -30.000000 & 51.799999 & INFINITY \\
HOSPMI22 & -25.000000 & 21.799999 & INFINITY \\
HOSPMI23 & -27.000000 & 22.799999 & INFINITY
\end{tabular}




$\begin{array}{lrrr}\text { HOSPMI24 } & -6.000000 & 2.800000 & \text { INFINITY } \\ \text { HOSPMI31 } & -16.950001 & 18.250000 & \text { INFINITY } \\ \text { HOSPMI32 } & -30.950001 & 30.250000 & \text { INFINITY } \\ \text { HOSPMI33 } & 1.050000 & 7.250000 & \text { INFINITY } \\ \text { HOSPMI34 } & -11.950000 & 10.250000 & \text { INFINITY } \\ \text { HOSPMI41 } & -10.300000 & 11.100000 & \text { INFINITY } \\ \text { HOSPMI42 } & -6.300000 & 6.100000 & \text { INFINITY } \\ \text { HOSPMI43 } & -5.300000 & 15.100000 & \text { INFINITY } \\ \text { HOSPMI44 } & -1.300000 & 2.100000 & \text { INFINITY } \\ \text { HOSPTY11 } & 2.000000 & 13.999999 & 2.000000 \\ \text { HOSPTY12 } & 6.000000 & 0.000000 & 6.000000 \\ \text { HOSPTY13 } & 3.000000 & 32.000000 & 3.000000 \\ \text { HOSPTY14 } & 5.000000 & 13.999999 & 5.000000 \\ \text { HOSPTY21 } & 3.000000 & 24.588234 & 2.470588 \\ \text { HOSPTY22 } & 4.000000 & 0.000000 & 3.000000 \\ \text { HOSPTY23 } & 3.000000 & 32.000000 & 1.000000 \\ \text { HOSPTY24 } & 4.000000 & 13.000000 & 4.000000 \\ \text { HOSPTY31 } & 2.000000 & 1.058823 & 2.000000 \\ \text { HOSPTY32 } & 10.000000 & 0.000000 & 10.000000 \\ \text { HOSPTY33 } & 5.000000 & 8.000000 & 5.000000 \\ \text { HOSPTY34 } & 14.000000 & 4.000000 & 14.000000 \\ \text { HOSPTY41 } & 1.000000 & 1.058823 & 1.000000 \\ \text { HOSPTY42 } & 8.000000 & 0.000000 & 7.000000 \\ \text { HOSPTY43 } & 7.000000 & 8.000000 & 6.000000 \\ \text { HOSPTY44 } & 5.000000 & 10.000000 & 2.470588\end{array}$


LP OPTIMUM FOUND AT STEP 18

OBJECTIVE FUNCTION VALUE

1) $\quad 12350.00$

\begin{tabular}{llr} 
VARIABLE & VALUE & REDUCED COST \\
\cline { 1 - 2 } PATS111 & 2.000000 & 0.000000 \\
PATS112 & 0.000000 & 360.000000 \\
PATS113 & 0.000000 & 200.000000 \\
PATS114 & 0.000000 & 420.000000 \\
PATS121 & 6.000000 & 0.000000 \\
PATS122 & 0.000000 & 360.000000 \\
PATS123 & 0.000000 & 400.000000 \\
PATS124 & 0.000000 & 420.000000 \\
PATS131 & 3.000000 & 0.000000 \\
PATS132 & 0.000000 & 360.000000 \\
PATS133 & 0.000000 & 200.000000 \\
PATS134 & 0.000000 & 420.000000 \\
PATS141 & 5.000000 & 0.000000 \\
PATS142 & 0.000000 & 180.000000 \\
PATS143 & 0.000000 & 200.000000 \\
PATS144 & 0.000000 & 210.000000 \\
PATS211 & 3.000000 & 0.000000 \\
PATS212 & 0.000000 & 0.000000 \\
PATS213 & 0.000000 & 10.000000 \\
PATS214 & 0.000000 & 230.000000 \\
PATS221 & 3.000000 & 0.000000 \\
PATS222 & 1.000000 & 0.000000 \\
PATS223 & 0.000000 & 210.000000 \\
PATS224 & 0.000000 & 230.000000 \\
PATS231 & 1.000000 & 0.000000 \\
PATS232 & 2.000000 & 0.000000 \\
PATS233 & 0.000000 & 10.000000 \\
PATS234 & 0.000000 & 230.000000 \\
PATS241 & 0.000000 & 180.000000 \\
PATS242 & 4.000000 & 0.000000 \\
& &
\end{tabular}




$\begin{array}{lrr}\text { PATS243 } & 0.000000 & 190.000000 \\ \text { PATS244 } & 0.000000 & 200.000000 \\ \text { PATS311 } & 0.000000 & 200.000000 \\ \text { PATS312 } & 0.000000 & 370.000000 \\ \text { PATS313 } & 2.000000 & 0.000000 \\ \text { PATS314 } & 0.000000 & 420.000000 \\ \text { PATS321 } & 10.000000 & 0.000000 \\ \text { PATS322 } & 0.000000 & 170.000000 \\ \text { PATS323 } & 0.000000 & 0.000000 \\ \text { PATS324 } & 0.000000 & 220.000000 \\ \text { PATS331 } & 0.000000 & 200.000000 \\ \text { PATS332 } & 0.000000 & 370.000000 \\ \text { PATS333 } & 5.000000 & 0.000000 \\ \text { PATS334 } & 0.000000 & 420.000000 \\ \text { PATS341 } & 0.000000 & 200.000000 \\ \text { PATS342 } & 0.000000 & 190.000000 \\ \text { PATS343 } & 14.000000 & 0.000000 \\ \text { PATS344 } & 0.000000 & 210.000000 \\ \text { PATS411 } & 1.000000 & 0.000000 \\ \text { PATS412 } & 0.000000 & 170.000000 \\ \text { PATS413 } & 0.000000 & 0.000000 \\ \text { PATS414 } & 0.000000 & 0.000000 \\ \text { PATS421 } & 7.000000 & 0.000000 \\ \text { PATS422 } & 0.000000 & 170.000000 \\ \text { PATS423 } & 0.000000 & 200.000000 \\ \text { PATS424 } & 1.000000 & 0.000000 \\ \text { PATS431 } & 0.000000 & 0.000000 \\ \text { PATS432 } & 0.000000 & 170.000000 \\ \text { PATS433 } & 6.000000 & 0.000000 \\ \text { PATS434 } & 1.000000 & 0.000000 \\ \text { PATS441 } & 0.000000 & 210.000000 \\ \text { PATS442 } & 0.000000 & 200.000000 \\ \text { PATS443 } & 0.000000 & 210.000000 \\ \text { PATS444 } & 5.000000 & 0.000000\end{array}$




\section{SLACK or}

\begin{tabular}{crr} 
ROW & SURPLUS & DUAL PRICES \\
\cline { 1 - 2 } HOSPCA11) & 19.000000 & 0.000000 \\
HOSPCA12) & 0.000000 & 180.000000 \\
HOSPCA13) & 13.000000 & 0.000000 \\
HOSPCA14) & 0.000000 & 210.000000 \\
HOSPCA21) & 0.000000 & 0.000000 \\
HOSPCA22) & 0.000000 & 180.000000 \\
HOSPCA23) & 0.000000 & 200.000000 \\
HOSPCA24) & 0.000000 & 210.000000 \\
HOSPCA31) & 32.000000 & 0.000000 \\
HOSPCA32) & 0.000000 & 180.000000 \\
HOSPCA33) & 8.000000 & 0.000000 \\
HOSPCA34) & 0.000000 & 210.000000 \\
HOSPCA41) & 14.000000 & 0.000000 \\
HOSPCA42) & 13.000000 & 0.000000 \\
HOSPCA43) & 4.000000 & 0.000000 \\
HOSPCA44) & 10.000000 & 0.000000 \\
HOSPTY11) & 0.000000 & -75.000000 \\
HOSPTY12) & 0.000000 & -75.000000 \\
HOSPTY13) & 0.000000 & -75.000000 \\
HOSPTY14) & 0.000000 & -75.000000 \\
HOSPTY21) & 0.000000 & -255.000000 \\
HOSPTY22) & 0.000000 & -255.000000 \\
HOSPTY23) & 0.000000 & -255.000000 \\
HOSPTY24) & 0.000000 & -75.000000 \\
HOSPTY31) & 0.000000 & -75.000000 \\
HOSPTY32) & 0.000000 & -275.000000 \\
HOSPTY33) & 0.000000 & -75.000000 \\
HOSPTY34) & 0.000000 & -75.000000 \\
HOSPTY41) & 0.000000 & -285.000000 \\
HOSPTY42) & 0.000000 & -285.000000 \\
HOSPTY43) & 0.000000 & -285.000000 \\
HOSPTY44) & 0.000000 & -75.000000 \\
HOSPRA12) & 16.000000 & 0.000000 \\
HO.000000 & 0.000000 \\
HOSP & 12.000000 & 0.000000 \\
& &
\end{tabular}




$\begin{array}{lrr}\text { HOSPRA14) } & 0.000000 & 0.000000 \\ \text { HOSPRA21) } & 0.800000 & 0.000000 \\ \text { HOSPRA22) } & 0.800000 & 0.000000 \\ \text { HOSPRA23) } & 0.000000 & 0.000000 \\ \text { HOSPRA24) } & 0.800000 & 0.000000 \\ \text { HOSPRA31) } & 27.799999 & 0.000000 \\ \text { HOSPRA32) } & 1.600000 & 0.000000 \\ \text { HOSPRA33) } & 9.200000 & 0.000000 \\ \text { HOSPRA34) } & 0.800000 & 0.000000 \\ \text { HOSPRA41) } & 15.200000 & 0.000000 \\ \text { HOSPRA42) } & 13.600000 & 0.000000 \\ \text { HOSPRA43) } & 14.400000 & 0.000000 \\ \text { HOSPRA44) } & 12.000000 & 0.000000\end{array}$

NO. ITERATIONS $=18$

RANGES IN WHICH THE BASIS IS UNCHANGED:

OBJ COEFFICIENT RANGES

CURRENT ALLOWABLE ALLOWABLE

\begin{tabular}{|c|c|c|c|}
\hline VARIABLE & COEF & INCREASE & DECREASE \\
\hline PATS111 & 75.000000 & 200.000000 & INFINITY \\
\hline PATS112 & 255.000000 & INFINITY & 360.000000 \\
\hline PATS113 & 275.000000 & INFINITY & 200.000000 \\
\hline PATS114 & 285.000000 & INFINITY & 420.000000 \\
\hline PATS121 & 75.000000 & 360.000000 & INFINITY \\
\hline PATS122 & 255.000000 & INFINITY & 360.000000 \\
\hline PATS123 & 275.000000 & INFINITY & 400.000000 \\
\hline PATS124 & 285.000000 & INFINITY & 420.000000 \\
\hline PATS131 & 75.000000 & 200.000000 & INFINITY \\
\hline PATS132 & 255.000000 & INFINITY & 360.000000 \\
\hline PATS133 & 275.000000 & INFINITY & 200.000000 \\
\hline PATS134 & 285.000000 & INFINITY & 420.000000 \\
\hline PATS141 & 75.000000 & 180.000000 & INFINITY \\
\hline PATS142 & 255.000000 & INFINITY & 180.000000 \\
\hline PATS143 & 275.000000 & INFINITY & 200.000000 \\
\hline
\end{tabular}




$\begin{array}{lrrr}\text { PATS144 } & 285.000000 & \text { INFINITY } & 210.000000 \\ \text { PATS211 } & 255.000000 & 10.000000 & 170.000000 \\ \text { PATS212 } & 75.000000 & 170.000000 & \text { INFINITY } \\ \text { PATS213 } & 265.000000 & \text { INFINITY } & 10.000000 \\ \text { PATS214 } & 275.000000 & \text { INFINITY } & 230.000000 \\ \text { PATS221 } & 255.000000 & 210.000000 & 170.000000 \\ \text { PATS222 } & 75.000000 & 170.000000 & \text { INFINITY } \\ \text { PATS223 } & 265.000000 & \text { INFINITY } & 210.000000 \\ \text { PATS224 } & 275.000000 & \text { INFINITY } & 230.000000 \\ \text { PATS231 } & 255.000000 & 10.000000 & 170.000000 \\ \text { PATS232 } & 75.000000 & 170.000000 & \text { INFINITY } \\ \text { PATS233 } & 265.000000 & \text { INFINITY } & 10.000000 \\ \text { PATS234 } & 275.000000 & \text { INFINITY } & 230.000000 \\ \text { PATS241 } & 255.000000 & \text { INFINITY } & 180.000000 \\ \text { PATS242 } & 75.000000 & 180.000000 & \text { INFINITY } \\ \text { PATS243 } & 265.000000 & \text { INFINITY } & 190.000000 \\ \text { PATS244 } & 275.000000 & \text { INFINITY } & 200.000000 \\ \text { PATS311 } & 275.000000 & \text { INFINITY } & 200.000000 \\ \text { PATS312 } & 265.000000 & \text { INFINITY } & 370.000000 \\ \text { PATS313 } & 75.000000 & 200.000000 & \text { INFINITY } \\ \text { PATS314 } & 285.000000 & \text { INFINITY } & 420.000000 \\ \text { PATS321 } & 275.000000 & 170.000000 & 200.000000 \\ \text { PATS322 } & 265.000000 & \text { INFINITY } & 170.000000 \\ \text { PATS323 } & 75.000000 & 200.000000 & \text { INFINITY } \\ \text { PATS324 } & 285.000000 & \text { INFINITY } & 220.000000 \\ \text { PATS331 } & 275.000000 & \text { INFINITY } & 200.000000 \\ \text { PATS332 } & 265.000000 & \text { INFINITY } & 370.000000 \\ \text { PATS333 } & 75.000000 & 200.000000 & \text { INFINITY } \\ \text { PATS334 } & 285.000000 & \text { INFINITY } & 420.000000 \\ \text { PATS341 } & 275.000000 & \text { INFINITY } & 200.000000 \\ \text { PATS342 } & 265.000000 & \text { INFINITY } & 190.000000 \\ \text { PATS343 } & 75.000000 & 190.000000 & \text { INFINITY } \\ \text { PATS344 } & 285.000000 & \text { INFINITY } & 210.000000 \\ \text { PATS11 } & 285.000000 & 0.000000 & 210.000000 \\ \text { PATS.000000 } & \text { INFINITY } & 170.000000 \\ \text { PA.0000000 } & 210.000000 & \text { INFINITY }\end{array}$




$\begin{array}{lrcc}\text { PATS421 } & 285.000000 & 170.000000 & 210.000000 \\ \text { PATS422 } & 275.000000 & \text { INFINITY } & 170.000000 \\ \text { PATS423 } & 285.000000 & \text { INFINITY } & 200.000000 \\ \text { PATS424 } & 75.000000 & 210.000000 & \text { INFINITY } \\ \text { PATS431 } & 285.000000 & \text { INFINITY } & 0.000000 \\ \text { PATS432 } & 275.000000 & \text { INFINITY } & 170.000000 \\ \text { PATS433 } & 285.000000 & 0.000000 & 210.000000 \\ \text { PATS434 } & 75.000000 & 210.000000 & \text { INFINITY } \\ \text { PATS441 } & 285.000000 & \text { INFINITY } & 210.000000 \\ \text { PATS442 } & 275.000000 & \text { INFINITY } & 200.000000 \\ \text { PATS443 } & 285.000000 & \text { INFINITY } & 210.000000 \\ \text { PATS444 } & 75.000000 & 200.000000 & \text { INFINITY }\end{array}$

RIGHTHAND SIDE RANGES

CURRENT ALLOWABLE ALLOWABLE

\begin{tabular}{crrrr} 
ROW & \multicolumn{1}{c}{ RHS } & & INCREASE & DECREASE \\
HOSPCA11 & 25.000000 & & INFINITY & 19.000000 \\
HOSPCA12 & 0.000000 & 3.000000 & 0.000000 \\
HOSPCA13 & 15.000000 & INFINITY & 13.000000 \\
HOSPCA14 & 0.000000 & 1.000000 & 0.000000 \\
HOSPCA21 & 26.000000 & INFINITY & 0.000000 \\
HOSPCA22 & 1.000000 & 3.000000 & 0.000000 \\
HOSPCA23 & 0.000000 & 10.000000 & 0.000000 \\
HOSPCA24 & 1.000000 & 7.000000 & 0.000000 \\
HOSPCA31 & 36.000000 & INFINITY & 32.000000 \\
HOSPCA32 & 2.000000 & 1.000000 & 2.000000 \\
HOSPCA33 & 19.000000 & INFINITY & 8.000000 \\
HOSPCA34 & 1.000000 & 6.000000 & 1.000000 \\
HOSPCA41 & 19.000000 & INFINITY & 14.000000 \\
HOSPCA42 & 17.000000 & INFINITY & 13.000000 \\
HOSPCA43 & 18.000000 & INFINITY & 4.000000 \\
HOSPCA44 & 15.000000 & INFINITY & 10.000000 \\
HOSPTY11 & 2.000000 & 19.000000 & 2.000000 \\
HOSPTY12 & 6.000000 & 0.000000 & 6.000000 \\
HOSPTY13 & 3.000000 & 32.000000 & 3.000000 \\
HOSPTY14 & 5.000000 & 14.000000 & 5.000000 \\
HOSPTY21 & 3.000000 & 16.000000 & 3.000000
\end{tabular}




$\begin{array}{lrrr}\text { HOSPTY22 } & 4.000000 & 0.000000 & 3.000000 \\ \text { HOSPTY23 } & 3.000000 & 27.799999 & 1.000000 \\ \text { HOSPTY24 } & 4.000000 & 13.000000 & 4.000000 \\ \text { HOSPTY31 } & 2.000000 & 13.000000 & 2.000000 \\ \text { HOSPTY32 } & 10.000000 & 0.000000 & 10.000000 \\ \text { HOSPTY33 } & 5.000000 & 8.000000 & 5.000000 \\ \text { HOSPTY34 } & 14.000000 & 4.000000 & 14.000000 \\ \text { HOSPTY41 } & 1.000000 & 16.000000 & 1.000000 \\ \text { HOSPTY42 } & 8.000000 & 0.000000 & 7.000000 \\ \text { HOSPTY43 } & 7.000000 & 8.000000 & 6.000000 \\ \text { HOSPTY44 } & 5.000000 & 10.000000 & 5.000000 \\ \text { HOSPRA11 } & 20.000000 & \text { INFINITY } & 16.000000 \\ \text { HOSPRA12 } & 0.000000 & \text { INFINITY } & 0.000000 \\ \text { HOSPRA13 } & 12.000000 & \text { INFINITY } & 12.000000 \\ \text { HOSPRA14 } & 0.000000 & \text { INFINITY } & 0.000000 \\ \text { HOSPRA21 } & 20.799999 & \text { INFINITY } & 0.800000 \\ \text { HOSPRA22 } & 0.800000 & \text { INFINITY } & 0.800000 \\ \text { HOSPRA23 } & 0.000000 & \text { INFINITY } & 0.000000 \\ \text { HOSPRA24 } & 0.800000 & \text { INFINITY } & 0.800000 \\ \text { HOSPRA31 } & 28.799999 & \text { INFINITY } & 27.799999 \\ \text { HOSPRA32 } & 1.600000 & \text { INFINITY } & 1.600000 \\ \text { HOSPRA33 } & 15.200000 & \text { INFINITY } & 9.200000 \\ \text { HOSPRA34 } & 0.800000 & \text { INFINITY } & 0.800000 \\ \text { HOSPRA41 } & 15.200000 & \text { INFINITY } & 15.200000 \\ \text { HOSPRA42 } & 13.600000 & \text { INFINITY } & 13.600000 \\ \text { HOSPRA43 } & 14.400000 & \text { INFINITY } & 14.400000 \\ \text { HOSPRA44 } & 12.000000 & \text { INFINITY } & 12.000000\end{array}$




\section{CURRICULUM VITAE}

NAME: Brandi Marie Hill

DOB: Louisville, Kentucky - May 28, 1980

EDUCATION: B.S. in Industrial Engineering University of Louisville

J.B. Speed School of Engineering $1998-2004$

MEng with specialization in the field of Industrial Engineering University of Louisville

J.B. Speed School of Engineering $2004-2005$

INTERNSHIP: Management Engineering Department of Norton Healthcare

AWARDS: $1^{\text {st }}$ - National Student Material Handling Design Competition $2002-2003$

$1^{\text {st }}$ - University of Louisville Technical Paper Competition 2003

UTA Resident Assistant of the Year 2004, 2005

Martin Luther King, Jr. Youth Service Award 1998

SCHOLARSHIPS: Woodford Porter Scholarship

Brown \& Williamson Scholarship

John Mann Scholarship

BWISE Foundation Scholarship

Salome C. Worthington Scholarship

National Council of Negro Women Scholarship

Louis-Edward Nicklies Scholarship

STUDENT MEMBERSHIPS: National Society of Black Engineers

Institute of Industrial Engineers

Society of Porter Scholars

Housing and Residence Life Student Judicial Board 